\title{
SOIL PHYSICAL QUALITY AFTER NITROGEN FERTILIZERS USE IN IRRIGATED PASTURE OF TIFTON 85
}

\author{
Qualidade física do solo após uso de adubos nitrogenados em pastagem irrigada de Tifton 85
}

\author{
Marina Luciana Abreu de Melo ${ }^{1 *}$; Eduardo Vieira Guimarães²; Bruno Montoani Silva ${ }^{3}$; Édio Luiz da Costa \\ Samuel Petraccone Caixeta ${ }^{4}$ \\ ${ }^{1}$ Agronomic Engineering Student; Agricultural Science Department; Federal University of São João del-Rei; \\ marinaluciana94@gmail.com \\ ${ }^{2}$ Interdisciplinary Biosystems Student; Exact and Biological Science Department; Federal University of São João del-Rei; \\ eduguimaraes.guimaraes@gmail.com \\ ${ }^{3}$ Associate Professor; Soil Science Department; Federal University of Lavras; brunom.silva@dcs.ufla.br \\ ${ }_{4}^{4}$ Associate Professor; Agricultural Science Department; Federal University of São João del-Rei; edio@ufsj.edu.br, \\ samuelcaixeta@ufsj.edu.br
}

Artigo enviado em 10/06/2017, aceito em 01/10/2017 e publicado em 20/12/2017.

\begin{abstract}
Tifton 85 (Cynodon sp.) is a forage crop widely used for the voluminous production, but it has also the potential to promote preservation or improvement in soil structural quality, when well managed. The aim of this work was to evaluate the soil physical quality in a rotational grazing area of Tifton 85 under irrigation in Prudente de Morais, MG, Brazil, due to the application of mineral and organic nitrogen fertilizers. The treatments included different forms of $\mathrm{N}$ supply: $400 \mathrm{~kg} \mathrm{ha}^{-1}$ of urea; $400 \mathrm{~kg} \mathrm{ha}^{-1}$ of bovine manure; $400 \mathrm{~kg} \mathrm{ha}^{-1}$ of urea and manure, in proportion 1:1 and the control, without nitrogen fertilization. The following soil physical quality indicators were determined in the layers $0.0-0.05 \mathrm{~m}$ and $0.05-0.10 \mathrm{~m}$ after two years of $\mathrm{N}$ application: water retention curve, total porosity, macroporosity, microporosity, soil bulk density, available water capacity, bulk soil air capacity, soil matrix air capacity and relative water capacity. There were differences among the treatments, in both layers. In general, the treatments using bovine manure promoted greater water storage and availability, which was related to the increase of the microporosity, due to the organic matter effect. However, these same treatments presented a relative compaction, which was associated to the maintenance of higher soil moistures. It was concluded that, even under the effects of intensive grazing, there was generally adequate soil physical quality, but a special attention is recommended to the soil susceptibility to compaction.
\end{abstract}

Keywords - water availability, soil aeration, organic fertilization, Cynodon sp.

Resumo - O Tifton 85 (Cynodon sp.) é uma cultura forrageira muito utilizada para a produção de volumosos, mas também demonstra potencial para promover preservação ou melhoria da qualidade estrutural do solo, quando bem manejada. O objetivo deste trabalho foi avaliar a qualidade física do solo em área de pastejo rotacionado de Tifton 85 irrigado em Prudente de Morais, MG, Brasil, em função da aplicação de adubos nitrogenados de origem mineral e orgânica. Os tratamentos incluíram diferentes formas de suprimento de N: $400 \mathrm{~kg} \mathrm{ha}^{-1}$ de ureia; $400 \mathrm{~kg} \mathrm{ha}^{-1}$ de esterco bovino; $400 \mathrm{~kg} \mathrm{ha-1}$ de ureia e esterco, na proporção 1:1 e a testemunha, sem adubação nitrogenada. Determinaram-se os seguintes indicadores de qualidade física do solo nas camadas 0.0-0.05 e 0.05-0.10 m, após dois anos de manejo: curva de retenção de água, porosidade total, macroporosidade, microporosidade, densidade do solo, capacidade de água disponível, capacidade de aeração do solo, capacidade de aeração da matriz do solo e capacidade relativa de água no solo. Houve diferenças entre os tratamentos, em ambas as camadas. Em geral, os tratamentos com o uso de esterco promoveram maior retenção e disponibilidade de água, o que foi relacionado ao incremento da microporosidade, devido ao efeito da matéria orgânica. No entanto, esses mesmos tratamentos apresentaram uma relativa compactação, o que foi associado à manutenção de maiores umidades no solo. Concluiu-se que, mesmo sob os efeitos do pastejo intensivo, houve em geral adequada qualidade física do solo, porém recomenda-se uma atenção especial quanto à suscetibilidade do solo à compactação.

Palavras-chave - disponibilidade de água, aeração, adubação orgânica, Cynodon sp. 


\section{INTRODUCTION}

According to the Municipal Livestock Survey published by IBGE (2016), Brazilian milk production reached 35 billion liters in 2015. The state of Minas Gerais had the highest production, reaching 9.14 billion liters, which represents $26.1 \%$ of the total national volume produced. This cattle-raising activity is still predominantly carried out through the adoption of extensive production systems, which are based on pastures as the main food source for animals. Considering this scenario, it is imperative the adoption of measures that promote improves on efficiency of pasture production and managements (MAGALHÃES et al., 2009; EUCLIDES et al., 2016).

In this context, we highlight the problem of inadequate pasture management in Brazil, which implies a decrease in soil physical quality. As consequences, it causes environmental harms, decrease in forage and animal production, resulting in financial losses to producers. Barducci et al. (2009) points out that approximately $80 \%$ of the Brazilian pastures show some level of degradation, and $50 \%$ of these are in an advanced stage. In Minas Gerais, about $75 \%$ of pastures have been degraded, which constitutes a real threat to the competitiveness of the livestock industry in relation to other Brazilian states (INAES, 2015).

Researches related to the structure of soils under forage crops have been frequently reported in literature (LIMA et al., 2012; SANTOS et al., 2012; FIDALSKI; TORMENA; ALVES, 2013; ORTIGARA et al., 2014; FIDALSKI, 2015) and the Tifton 85 (Cynodon sp.) has been prominent among other forage grasses. This specie is characterized by a dense root system with fast renewal, which confers the capacity of the biological soil decompression and the structure recovery of physically degraded soils (MAGALHÃES et al., 2009; COLUSSI; SILVA; MINATO, 2014).

Soil fertilization and irrigation use are considered management strategies that further pasture quality and productivity (ALENCAR et al., 2013). According to Pereira et al. (2012), nitrogen fertilization benefits the pastures productivity, since, in general, the nitrogen element improves flow in tissues of tropical grasses, which favors the cultural growth. Lima et al. (2012) also relate pasture fertilization to good root growth of forage species, promoting soil restructuring after physical degradation.

In addition, irrigated areas of Tifton 85 have shown considerable increases in the crop productivity (SANCHES et al., 2015). However, the intensification of soil use due to irrigation may lead to its structure compaction, considering the positive correlation between soil water content and susceptibility to compaction (LIMA et al., 2012). This phenomenon often increment soil bulk density and reduces pore volume, affecting soil water infiltration, soil aeration and water availability to plants, which raises the risk of erosion and impairs roots elongation (SHI et al., 2012; COLUSSI; SILVA; MINATO, 2014).

On the other hand, the improvements in the soil structural quality can be achieved by the addition of organic matter (BETIOLI JÚNIOR et al., 2012; OLIVEIRA et al., 2015). The increase in soil organic matter content favors the reduction of soil density and the increase of porosity, which often promotes adequate soil aeration to the plants (CUNHA et al., 2011). These benefits are associated to changes in the soil pores distribution by size, which increments the soil physical quality (RAMOS et al., 2013).

The forage requirements regarding soil fertility also must be taken into account, especially when it is destined to produce hay. In these production systems, there is a high demand for nutrients, which must be supplied continuously. Considering this fact, the organic fertilization may be a promising strategy, since it provides gradual release of nutrients, resulting in benefits to crops and to soil physical quality (COLUSSI; SILVA; MINATO, 2014).

It has been reported that the roots of Cynodon grasses have high vigor of growth, and it can favor the soil porosity (LIMA et al., 2012), especially under adequate nutrition conditions. In this context, it is hypothesized that the use of organic forms for nitrogen fertilization can promote preservation or improvement of the soil structure. Therefore, the aim of this study was to evaluate the physical quality of a soil under intensive grazing in an area of irrigated Tifton 85, as a function of different forms of $\mathrm{N}$ supply.

\section{MATERIALS AND METHODS}

The study was carried out in the Central region of Minas Gerais, Brazil, under the Cerrado biome, at an experimental area of approximately 1.8 ha in the Research Company of Minas Gerais, CentralWest Region (EPAMIG/CTCO), at coordinates $19^{\circ}$ $28^{\prime} 29^{\prime \prime} \mathrm{S}$ and $44^{\circ} 09^{\prime} 34^{\prime \prime} \mathrm{W}$, and the altitude of $759 \mathrm{~m}$. The regional climate according to the Köppen's global climatic classification is humid subtropical (Cwa), with an average annual temperature of $21.8{ }^{\circ} \mathrm{C}$ and annual rainfall of 1,329 $\mathrm{mm}$ (IBGE, 2013). The soil was classified as Haplustox (SOIL SURVEY STAFF, 1999). Table 1 presents the chemical and physical soil characterization. 
Table 1. Chemical $(0.0-0.20 \mathrm{~m})$ and physical characterization $(0.05-0.10$ and $0.05-0.10 \mathrm{~m})$ of the Haplustox.

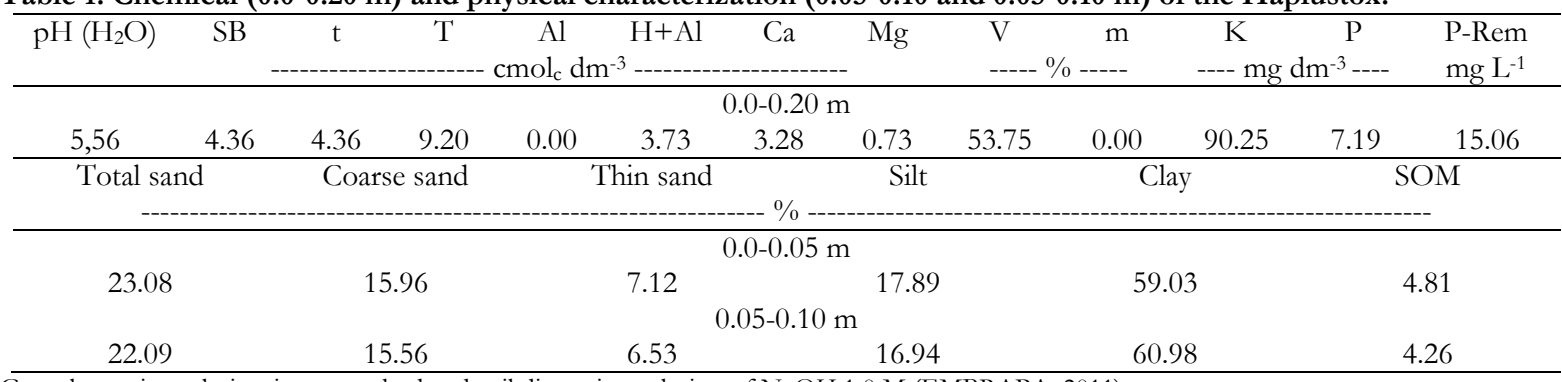

Granulometric analysis: pipette method and soil dispersing solution of NaOH 1,0 M (EMBRAPA, 2011).

SOM percentage: Walkley-Black method (WALKLEY; BLACK, 1934).

The experiment mounting occurred in January 2011, with use of plow and leveler harrow to prepare the soil. Two tons of dolomitic lime were applied for soil correction purposes and the planting fertilization spent $578 \mathrm{~kg}$ of fertilizer NPK 08:28:16 + Fritted Trace Elements (FTE) and $650 \mathrm{~kg}$ of fertilizer NPK 20:00:20. The pasture was planted in March, 2011. The area was subdivided into 24 pickets of 18 x $40 \mathrm{~m}$ and used for rotational grazing of cattle from August 2012 to April 2014, with an average of 50 animals per entry. After the last entry, the area was submitted to sporadic grazing, until the date of samplings.

Eight pickets were evaluated with four replications, in randomized blocks experimental design. The treatments tested were: $400 \mathrm{~kg} \mathrm{ha}^{-1}$ of $\mathrm{N}$ in mineral form via urea (Min); $400 \mathrm{~kg} \mathrm{ha}^{-1}$ of $\mathrm{N}$ in organic form via bovine manure (Org); $400 \mathrm{~kg} \mathrm{ha}^{-1}$ of $\mathrm{N}, 50 \%$ in mineral form and $50 \%$ in organic form, using the same sources (Orgmin) and the control, without $\mathrm{N}$ supply (Control). There were six applications in the range of $25,25,20,10,10$ and $10 \%$ of the $\mathrm{N}$ total dose. These treatments were applied in pickets with net sprinkler irrigation, according to the crop demand.

In July 2015, samples with undisturbed structure were taken in volumetric rings from the 0.0$0.05 \mathrm{~m}$ and $0.05-0.10 \mathrm{~m}$ layers. These samples were saturated to estimate the saturation volumetric water content and submitted to potentials $(\Psi)-1,-2,-4,-6$, $10 \mathrm{kPa}$, on a pF laboratory station (ecoTech), and -33 , $100,-500,-1500 \mathrm{kPa}$, in Richards extraction chambers. After the equilibrium at these potentials, the samples were dried in an oven at $105^{\circ} \mathrm{C}$ until the achievement of constant dry mass. The soil total porosity (TP) was determined as equal to the saturated volumetric water content of the bulk soil $\left(\mathrm{m}^{3} \mathrm{~m}^{-3}\right)$. The microporosity (Micro) was defined as equal to the water content at -6 $\mathrm{kPa}\left(\mathrm{m}^{3} \mathrm{~m}^{-3}\right)$ and the macroporosity (Macro) was obtained by the difference between TP and Micro $\left(\mathrm{m}^{3}\right.$ $\mathrm{m}^{-3}$ ). The soil bulk density (BD) was calculated by the ratio between the dried soil mass and the ring volume, expressed in $\mathrm{Mg} \mathrm{m}^{-3}$ (EMBRAPA, 2011).

The soil water retention curves (SWRC) were adjusted by the Van Genuchten model (1980), with Mualem restriction $[\mathrm{m}=1-(1 / \mathrm{n})]$, using the RetC software and according to the following equation:

$$
\theta=\theta \mathrm{r}+\frac{\theta \mathrm{s}-\theta \mathrm{r}}{\left[1+\left(\mathrm{x} \mid \Psi_{\mathrm{m}}\right)^{\mathrm{n}}\right]^{\mathrm{m}}}
$$

Where: $\theta=$ water content $\left(\mathrm{m}^{3} \mathrm{~m}^{-3}\right)$; $\theta \mathrm{r}=$ residual water content $\left(\mathrm{m}^{3} \mathrm{~m}^{-3}\right) ; \theta \mathrm{s}=$ saturated water content $\left(\mathrm{m}^{3} \mathrm{~m}^{-}\right.$ $\left.{ }^{3}\right) ; \Psi=$ soil water potential $(\mathrm{kPa}) ; \alpha=$ empirical parameter $\left(\mathrm{cm}^{-1}\right) ; \mathrm{m}, \mathrm{n}=$ empirical parameters.

The available water capacity (AWC) was determined by the difference between the volumetric water content at the field capacity $(-10 \mathrm{kPa})$ and the permanent willing point $(-1500 \mathrm{kPa})$. The bulk soil air capacity $\left(A C_{B}\right)$ was defined by the difference between the saturated volumetric water content and the field capacity. The soil matrix air capacity $\left(\mathrm{AC}_{\mathrm{M}}\right)$ was calculated by the difference between the equilibrium volumetric water content at -1 and $-10 \mathrm{kPa}$. The relative water capacity (RWC) was obtained by the ratio between the field capacity and the soil total porosity (REYNOLDS et al., 2008).

The R language was used to perform ShapiroWilk normality test, analysis of variance at $5 \%$ probability and mean comparison by Scott-Knott's test at 5\% using the ExpDes package (FERREIRA; CAVALCANTI; NOGUEIRA, 2014).

\section{RESULTS AND DISCUSSION}

The parameters $\mathrm{m}, \mathrm{n}, \boldsymbol{\alpha}, \theta \mathrm{s}, \theta \mathrm{r}$ of the Van Genuchten model and the determination coefficient $\left(\mathrm{R}^{2}\right)$ are shown in Table 2. For all treatments, in both layers, the $\mathrm{R}^{2}$ was above than 0.99 , which shows the good model suitability to the data. 
Table 2. Parameters of the adjustment model proposed by Van Genuchten (1980) and determination coefficient $\left(R^{2}\right)$ of water retention curves of the Haplustox for the treatments in the layers $0.0-0.05$ and $0.05-0.10 \mathrm{~m}$.

\begin{tabular}{|c|c|c|c|c|c|c|}
\hline Treatments & $\mathrm{m}$ & $\mathrm{n}$ & $\alpha$ & $\theta \mathrm{s}$ & $\theta \mathrm{r}$ & $\mathrm{R}^{2}$ \\
\hline & \multicolumn{6}{|c|}{$0.0-0.05 \mathrm{~m}$} \\
\hline Min & 0.095 & 1.105 & 3.812 & 0.554 & 0.108 & 0.998 \\
\hline Org & 0.071 & 1.076 & 0.696 & 0.516 & 0.033 & 0.999 \\
\hline Orgmin & 0.065 & 1.069 & 0.441 & 0.510 & 0.007 & 0.999 \\
\hline \multirow[t]{2}{*}{ Control } & 0.122 & 1.140 & 0.797 & 0.547 & 0.154 & 0.999 \\
\hline & \multicolumn{6}{|c|}{$0.05-0.10 \mathrm{~m}$} \\
\hline Min & 0.148 & 1.174 & 0.703 & 0.542 & 0.212 & 0.998 \\
\hline Org & 0.215 & 1.273 & 0.101 & 0.511 & 0.229 & 0.999 \\
\hline Orgmin & 0.148 & 1.173 & 0.194 & 0.523 & 0.195 & 0.998 \\
\hline Control & 0.175 & 1.213 & 0.332 & 0.530 & 0.215 & 0.998 \\
\hline
\end{tabular}

For the first layer, it was observed that the water retention curve of the Min treatment presented the highest slope at the inflection point ( $\mathrm{S}$ index), followed by the Control, the Org and the Orgmin treatments (Figure 1). In the second layer, the Org presented the lowest inclination at that point (Figure 2).

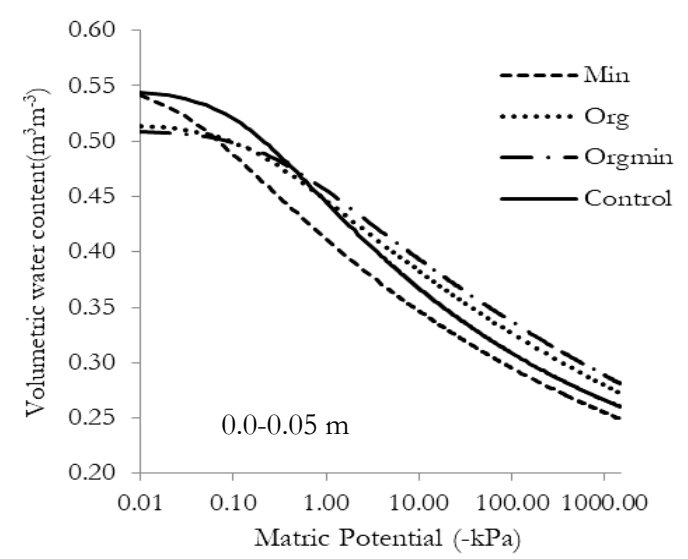

Figure 1. Water retention curves in the 0.0-0.05 m layer.

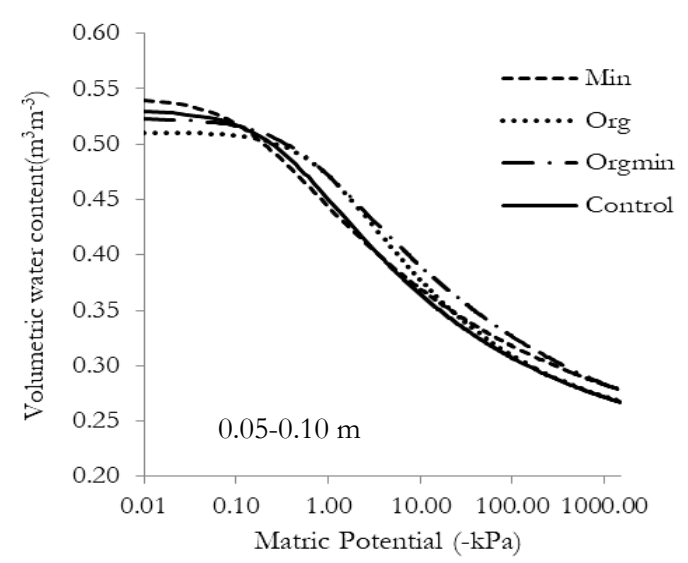

Figure 2. Water retention curves in the 0.05-0.10 m layer.
According to Carducci et al. (2011) and Silva et al. (2012), the curve shape reflects the soil pores distribution by size, which is affected by the soil management. Jardini and Amorim (2017), studying some physical attributes of different soils (Ultisols, Oxisols, Inceptisols and Entisols Quartzipsamments), found in the state of Mato Grosso, Brazil, under distinct uses (pastures, sugarcane, corn, soybeans and without agricultural use) in the Cerrado biome, verified a positive correlation between the $\mathrm{S}$ index and the soil organic carbon content. Li et al. (2011) also observed a positive association between the $\mathrm{S}$ index and the organic matter content of an Ultisol under different managements in the Southeast region of Australia, which contrasts with our results.

As stated by Reynolds et al. (2009), the use of the $\mathrm{S}$ index as a soil physical quality indicator may lead to wrong interpretations when it is applied in sandy soils and, in some cases, in soils with granular structure, as the Oxisols situated in the Brazilian Cerrado biome. In addition, Jong van Lier (2014) emphasized that the S index is incapable to predict the soil physical quality, since it is a static parameter to describe dynamic processes. Therefore, greater slopes at the inflection point do not necessarily mean better conditions to the plants growth.

Table 3 presents the determined points of the water retention curves for the treatments in the layers $0.0-0.05$ and $0.05-0.10 \mathrm{~m}$. By analyzing each point, we observed that the Org and the Orgmin treatments often promoted larger values of water content than the Min. Exceptions occurred at $0 \mathrm{kPa}$ in the $0.0-0.0 .5 \mathrm{~m}$ layer, at $0,-33,-100,-500 \mathrm{kPa}$ in the $0.05-0.10 \mathrm{~m}$ layer, in which there was no difference among the treatments, and at $-1500 \mathrm{kPa}$ in the same layer, in which the Org was below the Min treatment (Table 3). 
Table 3. Determined points of the water retention curves for the treatments in the layers 0.0-0.05 and 0.05-0.10 m.

\begin{tabular}{|c|c|c|c|c|c|c|c|c|c|c|}
\hline Treatments & $0 \mathrm{kPa}$ & $-1 \mathrm{kPa}$ & $-2 \mathrm{kPa}$ & $-4 \mathrm{kPa}$ & $-6 \mathrm{kPa}$ & $-10 \mathrm{kPa}$ & $-33 \mathrm{kPa}$ & $-100 \mathrm{kPa}$ & $-500 \mathrm{kPa}$ & $-1500 \mathrm{kPa}$ \\
\hline & \multicolumn{10}{|c|}{$0.0-0.05 \mathrm{~m}$} \\
\hline Min & $0.55 \mathrm{a}$ & $0.41 \mathrm{~b}$ & $0.39 \mathrm{~b}$ & $0.37 \mathrm{~b}$ & $0.36 \mathrm{~b}$ & $0.35 \mathrm{~d}$ & $0.31 \mathrm{c}$ & $0.29 \mathrm{~b}$ & $0.26 \mathrm{~b}$ & $0.25 \mathrm{~d}$ \\
\hline Org & $0.51 \mathrm{~b}$ & $0.44 \mathrm{a}$ & $0.43 \mathrm{a}$ & $0.41 \mathrm{a}$ & $0.39 \mathrm{a}$ & $0.37 \mathrm{c}$ & $0.35 \mathrm{a}$ & $0.33 \mathrm{a}$ & $0.29 \mathrm{a}$ & $0.27 \mathrm{~b}$ \\
\hline Orgmin & $0.51 \mathrm{~b}$ & $0.45 \mathrm{a}$ & $0.44 \mathrm{a}$ & $0.42 \mathrm{a}$ & $0.41 \mathrm{a}$ & $0.38 \mathrm{~b}$ & $0.36 \mathrm{a}$ & $0.34 \mathrm{a}$ & $0.30 \mathrm{a}$ & $0.28 \mathrm{a}$ \\
\hline Control & $0.55 \mathrm{a}$ & $0.44 \mathrm{a}$ & $0.42 \mathrm{a}$ & $0.40 \mathrm{a}$ & $0.38 \mathrm{a}$ & $0.39 \mathrm{a}$ & $0.33 \mathrm{~b}$ & $0.31 \mathrm{~b}$ & $0.27 \mathrm{~b}$ & $0.26 \mathrm{c}$ \\
\hline CV $(\%)$ & 2.51 & 1.69 & 3.17 & 4.04 & 3.75 & 1.21 & 3.64 & 3.46 & 3.94 & 1.84 \\
\hline & \multicolumn{10}{|c|}{$0.05-0.10 \mathrm{~m}$} \\
\hline Min & $0.54 \mathrm{~ns}^{1}$ & $0.44 \mathrm{~b}$ & $0.42 \mathrm{~b}$ & $0.39 \mathrm{~b}$ & $0.38 \mathrm{~b}$ & $0.37 \mathrm{~b}$ & $0.34 \mathrm{~ns}^{1}$ & $0.32 \mathrm{~ns}^{1}$ & $0.29 \mathrm{~ns}^{1}$ & $0.28 \mathrm{a}$ \\
\hline Org & 0.51 & $0.47 \mathrm{a}$ & $0.45 \mathrm{a}$ & $0.41 \mathrm{a}$ & $0.40 \mathrm{a}$ & $0.38 \mathrm{a}$ & 0.34 & 0.31 & 0.28 & $0.27 \mathrm{~b}$ \\
\hline Orgmin & 0.52 & $0.46 \mathrm{a}$ & $0.45 \mathrm{a}$ & $0.43 \mathrm{a}$ & $0.41 \mathrm{a}$ & $0.39 \mathrm{a}$ & 0.35 & 0.33 & 0.29 & $0.28 \mathrm{a}$ \\
\hline Control & 0.53 & $0.45 \mathrm{~b}$ & $0.42 \mathrm{~b}$ & $0.40 \mathrm{~b}$ & $0.38 \mathrm{~b}$ & $0.36 \mathrm{~b}$ & 0.33 & 0.31 & 0.28 & $0.27 \mathrm{~b}$ \\
\hline $\mathrm{CV}(\%)$ & 3.37 & 2.15 & 2.93 & 2.77 & 1.75 & 2.17 & 3.02 & 3.44 & 2.74 & 2.75 \\
\hline
\end{tabular}

Means followed by the same letter in the column did not differ by Scott-Knott's test $(\mathrm{p}<0.05) .{ }^{1}$ Not significant. CV = Coefficient of Variation.

The Control did not differ from the Org and the Orgmin treatments at $-1,-2,-4,-6 \mathrm{kPa}$ in the first layer, but it showed lower values at $-10,-33$, $100,-500,-1500 \mathrm{kPa}$ and at $-1,-2,-4,-6,-10 \mathrm{kPa}$ in the second layer. Only at $0 \mathrm{kPa}$, the Control was greater than the Org and the Orgmin treatments in the first layer. Therefore, we observed that the organic matter addition often promoted higher water retention in the soil.

According to Hillel (1998), the water retention is a function of capillarity and adsorption phenomena, which are influenced by the soil texture, mineralogy, organic matter content, soil structure and others factors. Braida et al. (2011) highlighted that the organic matter has direct and indirect influences on soil water retention. The direct effects are thanks to its hygroscopicity and its large specific surface area, while the indirect effects are due to the structural changes promoted by its different contents in the soil. As observed by Barros et al. (2016) and Dexter et al.
(2008), the organic matter increment in soils favors the pores with smaller diameters, which are associated to greater water storage.

Some researchers have found a positive association between organic matter and water retention in soils with clayey or medium texture (MACHADO et al.; 2008; BOULAL et al., 2011; ALENCAR et al., 2015). As suggested by Costa (1979), the soil texture largely influences the soil capacity to water retention. However, within soils with the same textural class, the behavior can be different due to distinct organic matter contents.

According to Table 4, the Org and the Orgmin treatments presented a total porosity and a macroporosity (Macro) lower than the Min and the Control in the 0.0-0.05 m layer, as well as a higher bulk density and a greater microporosity (Micro) than the Min. In the 0.05-0.10 $\mathrm{m}$ layer, the behavior for Macro and Micro were similar, but for TP and BD, there was no difference among the treatments.

Table 4. Physical attributes total porosity (TP), macroporosity (Macro), microporosity (Micro) and bulk density (BD) of the Haplustox for the treatments in the layers 0.0-0.05 and 0.05-0.10 m.

\begin{tabular}{|c|c|c|c|c|}
\hline \multirow{2}{*}{ Treatments } & $\mathrm{TP}$ & Macro & Micro & $\mathrm{BD}$ \\
\hline & \multicolumn{3}{|c|}{-------------------- $\left(\mathrm{m}^{3} \mathrm{~m}^{-3}\right)$---------- } & $\left(\mathrm{Mg} \mathrm{m}^{-3}\right)$ \\
\hline \multicolumn{5}{|c|}{$0.0-0.05 \mathrm{~m}$} \\
\hline Min & $0.55 \mathrm{a}$ & $0.19 \mathrm{a}$ & $0.36 \mathrm{~b}$ & $1.05 \mathrm{~b}$ \\
\hline Org & $0.51 \mathrm{~b}$ & $0.12 \mathrm{~b}$ & $0.39 \mathrm{a}$ & $1.20 \mathrm{a}$ \\
\hline Orgmin & $0.51 \mathrm{~b}$ & $0.10 \mathrm{~b}$ & $0.41 \mathrm{a}$ & $1.24 \mathrm{a}$ \\
\hline Control & $0.55 \mathrm{a}$ & $0.17 \mathrm{a}$ & $0.38 \mathrm{a}$ & $1.12 \mathrm{~b}$ \\
\hline $\mathrm{CV}(\%)$ & 2.51 & 16.13 & 3.75 & 5.64 \\
\hline \multicolumn{5}{|c|}{$0.05-0.10 \mathrm{~m}$} \\
\hline Min & $0.54 \mathrm{~ns}^{1}$ & $0.16 \mathrm{a}$ & $0.38 \mathrm{~b}$ & $1.12 \mathrm{~ns}^{1}$ \\
\hline Org & 0.51 & $0.11 \mathrm{~b}$ & $0.40 \mathrm{a}$ & 1.18 \\
\hline Orgmin & 0.52 & $0.12 \mathrm{~b}$ & $0.41 \mathrm{a}$ & 1.16 \\
\hline Control & 0.53 & $0.15 \mathrm{a}$ & $0.38 \mathrm{~b}$ & 1.19 \\
\hline $\mathrm{CV}(\%)$ & 3.37 & 8.86 & 1.75 & 4.64 \\
\hline
\end{tabular}


These results indicate a relative soil structure compaction in the treatments with organic matter addition, since this phenomenon can be detected by the increase of soil bulk density (BD), the reduction of total porosity (TP) and, principally, by the decrease of Macro (ARSHAD; LOWERY; GROSSMAN, 1996; ARAÚJO et al., 2012). Considering the organic matter hygroscopicity and the comparisons of the soil water retention among the treatments, it is probable that the Org and the Orgmin treatments promoted the maintenance of greater soil moisture and this effect, combining to the animal trampling, intensified the soil compaction in these treatments. Ortigara et al. (2014), evaluating physical attributes of an Oxisol situated in the state of Rio Grande do Sul, Brazil, and submitted to different managements (rotated pasture of Tifton 85 , annual crops and native forest), verified a negative alteration in the soil structure promoted by intensive trampling, which was shown through soil compaction indicators, including the soil bulk density.

Despite the relative soil compaction in the Org and the Orgmin treatments, the TP, Macro and $\mathrm{BD}$ indicators remained within the critical limits recommended for adequate soil physical quality. All determined values for TP were equal to or higher than the minimum value of $0.50 \mathrm{~m}^{3} \mathrm{~m}^{-3}$ proposed by Andrade and Stone (2009). Values of Macro were also equal to or greater than the critical limit of $0.10 \mathrm{~m}^{3} \mathrm{~m}^{-3}$ (OLIVEIRA; SEVERIANO; MELLO, 2007) (Table 4). After the cultivation of Tifton 85 in an Ultisol found in the city of Lavras, Minas Gerais, Brazil, Magalhães et al. (2009) also observed higher values than the critical limit for Macro, which were related to the soil restructuring promoted by the mechanical action of the Tifton 85 roots system.
In reference to $\mathrm{BD}$, Reichert, Suzuki and Reinert (2007) defined the critical value of $1.45 \mathrm{Mg} \mathrm{m}^{-3}$ for soils with clay content upper than $55 \%$. Specifically regarding the Tifton 85, Magalhães et al. (2009) considered that a $\mathrm{BD}$ equivalent to $1.28 \mathrm{Mg} \mathrm{m}^{-3}$ is restrictive to its proper development. According to these references, there was no limitation to the crop, since the maximum reached value was $1.24 \mathrm{Mg} \mathrm{m}^{-3}$ (Table 4). Besides, the obtained values of $\mathrm{BD}$ were similar to those verified by Lima et al. (2012), studying physical attributes of an Oxisol located in the city of Itutinga, Minas Gerais, Brazil, after one year of the Cynodon dactylon cultivation, in order to promote soil physical quality recovery.

Regarding the results for Micro, the organic matter favored an increase of the smaller pores frequency in the TP, as observed by Barros et al. (2016) in samplings of Oxisol with anthropic horizon and situated in a forest area in the state of Pará, Brazil. Furthermore, there was a probable influence of the soil compaction, which can be induced the fragmentation of macropores into micropores. The values were similar to those observed by Magalhães et al. (2009) in an Ultisol, but distinct to the results obteined by Colussi, Silva and Minato (2014), in a Alfisol cultivated with Tifton 85 and located in the Southwest region of the state of Paraná, Brazil. These authors found values for Micro above $0.46 \mathrm{~m}^{3} \mathrm{~m}^{-3}$, which can be associated to the distinct soil class and the scarifier use, which implies soil structural changes.

The higher soil water storage in the Org and the Orgmin treatments implies greater water availability than in the Min, in both layers. On the other hand, the AWC for those treatments differed from the Control only in the $0.05-0.10 \mathrm{~m}$ layer (Table 5).

Table 5. Physical attributes available water capacity $(A W C)$, bulk soil air capacity $\left(A C_{B}\right)$, soil matrix air capacity $\left(A_{M}\right)$ and relative water capacity (RWC) of the Haplustox for the treatments in the layers 0.0-0.05 and 0.05-0.10 m.

\begin{tabular}{|c|c|c|c|c|}
\hline \multirow{2}{*}{ Treatments } & AWC & $\mathrm{AC}_{\mathrm{B}}$ & $\mathrm{AC}_{\mathrm{M}}$ & RWC \\
\hline & \multicolumn{4}{|c|}{$\left(\mathrm{m}^{3} \mathrm{~m}^{-3}\right)$} \\
\hline \multicolumn{5}{|c|}{$0.0-0.05 \mathrm{~m}$} \\
\hline Min & $0.10 \mathrm{~b}$ & $0.20 \mathrm{a}$ & $0.06 \mathrm{~b}$ & $0.63 \mathrm{c}$ \\
\hline Org & $0.11 \mathrm{a}$ & $0.13 \mathrm{~b}$ & $0.06 \mathrm{~b}$ & $0.75 \mathrm{a}$ \\
\hline Orgmin & $0.11 \mathrm{a}$ & $0.12 \mathrm{~b}$ & $0.06 \mathrm{~b}$ & $0.78 \mathrm{a}$ \\
\hline Control & $0.11 \mathrm{a}$ & $0.18 \mathrm{a}$ & $0.08 \mathrm{a}$ & $0.67 \mathrm{~b}$ \\
\hline CV $(\%)$ & 5.37 & 9.08 & 14.08 & 2.75 \\
\hline \multicolumn{5}{|c|}{$0.05-0.10 \mathrm{~m}$} \\
\hline Org & $0.11 \mathrm{a}$ & $0.13 \mathrm{~b}$ & $0.09 \mathrm{a}$ & $0.73 \mathrm{a}$ \\
\hline Orgmin & $0.11 \mathrm{a}$ & $0.13 \mathrm{~b}$ & $0.07 \mathrm{~b}$ & $0.74 \mathrm{a}$ \\
\hline Control & $0.10 \mathrm{~b}$ & $0.17 \mathrm{a}$ & $0.09 \mathrm{a}$ & $0.68 \mathrm{~b}$ \\
\hline CV $(\%)$ & 7.39 & 8.66 & 10.95 & 2.28 \\
\hline
\end{tabular}

Means followed by the same letter in the column did not differ by Scott-Knott's test $(\mathrm{p}<0.05) .{ }^{1}$ Not significant. CV = Coefficient of Variation. 
According to Braida et al. (2011), there is no consensus on the contribution of organic matter to the water availability in soils and part of these divergences is thanks to the distinct procedures adopted to evaluate this relation. Nevertheless, there are some studies that verified this association, as the research conducted by Barzegar, Yousefi and Daryashenas (2002) in an Iranian Inceptisol, where it was observed that the addition of farmyard manure, wheat residues and sugarcane bagasse compost increased the available water in the soil. Similar results were obtained by Fernandes et al. (2012), studying the use of different fertilizer strategies (bovine manure, chicken manure, cassava agroindustry residue, phosphate fertilization and green manure) in an Oxisol found in Terra Alta, Paraná, Brazil.

Concerning the soil aeration, the bulk soil air capacity was lower in the Org and the Orgmin treatments in both layers, due to the reduction of the larger pores. However, the values were above or within the critical interval of $0.10-0.15 \mathrm{~m}^{3} \mathrm{~m}^{-3}$ assumed by Reynolds et al. (2002) to the adequate roots system aeration (Table 5). Thus, it seems that none of the treatments expressed limiting conditions to the Tifton 85 roots system, but the Min and the Control presented better aeration conditions. Fidalski et al. (2008), studying some physical attributes of an Oxisol under a Cynodon pasture in the Northwest region of Paraná, Brazil, found values of $\mathrm{AC}_{\mathrm{B}}$ predominantly greater than those found in our study $\left(0.19-0.22 \mathrm{~m}^{3} \mathrm{~m}^{-3}\right.$ to $\left.0.12-0.20 \mathrm{~m}^{3} \mathrm{~m}^{-3}\right)$, but the soil analyzed by them had a sandy texture, which naturally tends to present an upper aeration capacity than clayey soils, thanks to their larger values of macroporosity.

About the soil matrix air capacity, there was no difference among the treatments with $\mathrm{N}$ supply in the 0.0-0.05 m layer, but they expressed values below the Control. In the $0.05-0.10 \mathrm{~m}$ layer, the Org was equal to the Control and both were higher than the other treatments, which were equal to each other (Table 5). Hence, we could not stablish a relation between the soil organic matter content and the attribute $\mathrm{AC}_{\mathrm{M}}$, suggesting that this parameter is little influenced by the organic matter. Fidalski et al. (2008) also determined the $\mathrm{AC}_{\mathrm{M}}$, finding values from 0.16 to $0.19 \mathrm{~m}^{3} \mathrm{~m}^{-3}$, which were considerably greater than our values ( 0.06 to $\left.0.08 \mathrm{~m}^{3} \mathrm{~m}^{-3}\right)$, indicating that the soil texture has a large influence in the $\mathrm{AC}_{\mathrm{M}}$ value. Besides, according to Reynolds et al. (2008), an $\mathrm{AC}_{\mathrm{M}}$ criterion has not yet been fixed, but they consider that an $\mathrm{AC}_{\mathrm{M}}$ upper than $0.10 \mathrm{~m}^{3} \mathrm{~m}^{-3}$ appears to be acceptable. Thus, our results indicated an improper physical quality in all treatments applied, as a function of this parameter.
The balance between water availability and aeration conditions can be expressed by the relative water capacity, which presented greater values in the Org and the Orgmin treatments, in both layers (Table 5). These results characterize the higher soil water storage caused by organic matter addition, as also verified by Fidslski et al. (2008) and Machado et al. (2008). However, the optimal RWC values are within the range of $0.60-0.70 \mathrm{~m}^{3} \mathrm{~m}^{-3}$ (REYNOLDS et al., 2008), which indicates that those treatments could harm the crop development, due to the insufficient aeration caused by soil compaction. For this attribute, Fidalski et al. (2008) achieved values from 0.43 to 0.49 $\mathrm{m}^{3} \mathrm{~m}^{-3}$, denoting that the RWC tends to be lower in sandy soils comparing to clayey soils.

\section{CONCLUSIONS}

The organic and organic/mineral forms of $\mathrm{N}$ supply in an irrigated pasture of Tifton 85 during a two-year period influence the soil physical quality, often favoring pores with smaller diameters, which results in a higher water storage and availability to the plants. However, these same fertilizers also can raise the soil susceptibility to compaction due to reduction in aeration capacity, which demands a special attention in intensive grazing managements.

\section{ACKNOWLEDGEMENTS}

The authors thank the National Council for Scientific and Technological Development (CNPq) for funding the study, the Agricultural Research Company of Minas Gerais, Central-West Region (EPAMIG/ CTCO) and the Agricultural Science Department of the Federal University of São João del-Rei (DCIAGUFSJ) for the infrastructure and support.

\section{REFERENCES}

ALENCAR, C. A. B.; CUNHA, F. F.; MARTINS, C. E.; CÓSER, A. C.; OLIVEIRA, R. A.; ARAÚJO, R. A. S. Adubação nitrogenada e estações anuais na produção de capins irrigados no leste mineiro sob corte. Revista Brasileira de Saúde e Produção Animal, v. 14, n. 3, p. 413-425, 2013. 
ALENCAR, T. L.; CHAVES, A. F.; SANTOS, C. L. A.; ASSIS JÚNIOR, R. N.; MOTA, J. C. A. Atributos físicos de um Cambissolo cultivado e tratado com biofertilizante na Chapada do Apodi, Ceará. Revista Brasileira de Ciência do Solo, v. 39, n. 3, 2015.

ANDRADE, R. S.; STONE, L. F. Índice S como indicador da qualidade física de solos do cerrado brasileiro. Revista Brasileira de Engenharia Agricola $e$ Ambiental, v. 13, n. 4, p. 382-388, 2009.

ARAÚJO, E. A.; KER, J. C.; NEVES, J. C. L.; LANI, J. L. Qualidade do solo: conceitos, indicadores e avaliação. Applied Research and Agrotechnology, v. 5, n. 1, p. 187-206, 2012.

ARSHAD, M. A.; LOWERY, B.; GROSSMAN, B. Physical tests for monitoring soil quality. In: DORAN, J.W. and JONES, A. J., eds. Methods for assessing soil quality. Madison, Soil Science Society of America. 1996. p. 123-141 (SSSA Special publication 49).

BARDUCCI, R. S.; COSTA, C.; CRUSCIOL, C. A. C.; BORGHI, É.; PUTAROV, T. C.; SARTI, L .M. N. Produção de Brachiaria brizantha e Panicum maximum com milho e adubação nitrogenada. Archivos de Zootecnia, v. 58, p. 211-222, 2009.

BARROS, K. R. M.; LIMA, H. V.; RODRIGUES, S.; KERN, D. C. Distribuição da porosidade textural e estrutural em solos de Terra Preta Arqueológica. Revista Ciência Agronômica, v. 47, n. 4, p. 609-615, 2016.

BARZEGAR, A. R.; YOUSEFI, A.; DARYASHENAS, A. The effect of addition of different amounts and types of organic materials on soil physical properties and yield of wheat. Plant and soil, v. 247 , n. 2, p. 295-301, 2002.

BETIOLI JÚNIOR, E.; MOREIRA, W. H.; TORMENA, C. A.; FERREIRA, C. J. B.; SILVA, A. P.; GIAROLA, N. F. B. Intervalo hídrico ótimo e grau de compactação de um Latossolo Vermelho após 30 anos sob plantio direto. Revista Brasileira de Ciência do Solo, v. 36, p. 971-982, 2012.

BOULAL, H.; GÓMEZ-MACPHERSON, H.; GÓMEZ, J. A.; MATEOS, L. Effect of soil management and traffic on soil erosion in irrigated annual crops. Soil and Tillage Research, v. 115, p. 62-70, 2011.
BRAIDA, J. A.; BAYER, C.; ALBUQUERQUE, J. A.; REICHERT, J. M. Matéria orgânica e seu efeito na física do solo. In: Tópicos em ciência do solo. Viçosa, MG, Sociedade Brasileira de Ciência do Solo, v. 7, p. 221278, 2011.

CARDUCCI, C. E.; OLIVEIRA, G. C.; SEVERIANO, E. C.; ZEVIANI, W. M. Modelagem da curva de retenção de água de Latossolos utilizando a equação duplo Van Genuchten. Revista Brasileira de Ciência do Solo, Viçosa, v.3 5, n. 1, p. 77-86, fev. 2011.

COluSsI, G; SILVA, L. S.; MINATO, E. A. Escarificação e adubação orgânica: efeito na recuperação estrutural de solo produzindo Tifton 85 . Ciência Rural, Santa Maria, v. 44, n. 11, p. 1956-1961, nov, 2014.

COSTA, J. B. Caracterização e constituição do solo. 29.ed. Lisboa: Fundação Calouste Gulbenkion, 1979. 527 p.

CUNHA, E. Q.; STONE, L. F.; MOREIRA, J. A. A.; FERREIRA, E. P. B.; DIDONET, A. D.; LEANDRO, W. M. Sistemas de preparo do solo e culturas de cobertura na produção orgânica de feijão e milho. I - Atributos físicos do solo. Revista Brasileira de Ciência do Solo, v. 35, p. 589-602, 2011.

DEXTER, A. R.; RICHARD, G.; ARROUAYS, D.; CZYŻ, E. A.; JOLIVET, C.; DUVAL, O. Complexed organic matter controls soil physical properties. Geoderma, v. 144, p. 620-627, 2008.

EMBRAPA. Manual de Métodos de Análise de Solo. 2. ed. Rio de Janeiro - RJ: Documento 182, Embrapa Solos, Centro Nacional de Pesquisa de Solos. Embrapa Produção de Informação, 2011.

EUClIDES, V. P. B.; MONTAGNER, D. B.; BARBOSA, R. A.; VALLE, C. B. D.; NANTES, N. $\mathrm{N}$. Animal performance and sward characteristics of two cultivars of Brachiaria brizantha (BRS Paiaguás and BRS Piatã). Revista Brasileira de Zootecnia, v. 45, n. 3, p. 85-92, 2016.

FERNANDES, A. R.; BRAZ, A. M. S.; SANTOS, R. S.; MOREIRA, N. B.; LIMA, H. V.; CRAVO, M. S. Estoque de carbono orgânico e intervalo hídrico ótimo em Latossolo Amarelo sob adubação orgânica. Revista de Ciências Agrárias/Amazonian Journal of Agricultural and Environmental Sciences, v. 54, n. 2, p. 144-152, 2012. 
FERREIRA, E. B.; CAVALCANTI, P. P.; NOGUEIRA, D. A. ExpDes: an $\mathrm{R}$ package for ANOVA and experimental designs. Applied Mathematics, Alfenas, v. 5, n. 19, p. 2952, 2014.

FIDALSKI, J. Qualidade física de Latossolo Vermelho em sistema de integração lavoura-pecuária após cultivo de soja e pastejo em braquiária. Pesquisa agropecuária brasileira, Brasília, v. 50, n. 11, p. 1097-1104, nov. 2015.

FIDALSKI, J.; TORMENA, C. A.; CECATO, U.; BARBERO, L. M.; LUGÃO, S. M. B.; COSTA, M. A. T. Qualidade física do solo em pastagem adubada e sob pastejo contínuo. Pesquisa Agropecuária Brasileira, v. 43, n. 11, p. 1583-1590, 2008.

FIDALSKI, J.; TORMENA, C. A.; ALVES, S. J. Intervalo hídrico ótimo de um Latossolo Vermelho distrófico, após o primeiro período de pastejo contínuo de Brachiaria ruziziensis, em sistema integração lavourapecuária. Revista Brasileira de Ciência do Solo, v. 37, p. 775783, 2013.

HILLEL, D. Environmental soil physics. San Diego, Academic Press, 1998. 771 p.

IBGE. Minas Gerais, Prudente de Morais, infográficos: histórico. IBGE Cidades, 2013.

IBGE. Pesquisa Pecuária Municipal, v. 43, 2015. IBGE, Diretoria de Agropecuária, Recursos Naturais e Geografia, 2016.

INSTITUTO ANTONIO ERNESTO DE SALVO INAES. Estado da Arte das pastagens em Minas Gerais. Belo Horizonte, 2015. 207 p.

JARDINI, D. C.; AMORIM, R. S. S. Uso do índice S na avaliação da qualidade físico-hídrica de solos do Cerrado matogrossense. Engenharia na Agricultural Engineering in Agriculture, v. 25, n. 2, p. 107-115, 2017.

JON VAN LIER, Q. Revisiting the S-index for soil physical quality and its use in Brazil. Revista Brasileira de Ciência do Solo (Impresso), v. 38, p. 1-10, 2014.

LI, L.; CHAN, K. Y.; NIU, Y.; OATES, A; DEXTER, A. R; HUANGET, G. Soil physical qualities in an Oxic Paleustalf under different tillage and stubble management practices and application of S theory. Soil and Tillage Research, v. 113, p. 82-88, 2011.
LIMA, V. M. P.; OLIVEIRA, G. C.; SERAFIM, M. E.; CURI, N.; EVANGELISTA, A. R. Intervalo hídrico ótimo como indicador de melhoria da qualidade estrutural de Latossolo degradado. Revista Brasileira de Ciência do Solo, v. 36, p.71-78, 2012.

MACHADO, J. L.; TORMENA, C. A.; FIDALSKI, J.; SCAPIM, C. A. Inter-relações entre as propriedades físicas e os coeficientes da curva de retenção de água de um Latossolo sob diferentes sistemas de uso. Revista Brasileira de Ciência do Solo, v. 32, n. 2, p. 495-502, 2008.

MAGALHÃES, E. N.; OLIVEIRA, G. C.; SEVERIANO, E. C.; COSTA, K. A. P.; CASTRO, M. B. Recuperação estrutural e produção de Capim-Tifton 85 em um Argissolo Vermelho-Amarelo compactado. Ciência Animal Brasileira, v. 10, n. 1, p. 68-76, 2009.

OLIVEIRA, G. C.; SEVERIANO, E. C.; MELLO, C. R. Dinâmica da resistência à penetração de um Latossolo Vermelho da Microrregião de Goiânia, GO. Revista Brasileira de Engenharia Agrícola e Ambiental, Campina Grande, v. 11, p. 265-270, 2007.

OLIVEIRA, G. G.; SILVA, É. A.; OLIVEIRA, G. C.; CARDUCCI, C. E.; BARBOSA, S. M.; SILVA, B. M. Indicadores de qualidade física para Argissolos sob pastagens nas regiões leste e sul de Minas Gerais. Revista de Ciências Agrárias/Amazonian Journal of Agricultural and Environmental Sciences, v. 58, n. 4, p. 388395, 2015.

ORTIGARA, C.; KOPPE, E.; LUZ, F. B; BERTOLLO, A. M.; KAISER, D. R.; SILVA, V. R. Uso do solo e propriedades físico-mecânicas de Latossolo Vermelho. Revista Brasileira de Ciência do Solo, v. 38, n. 2, p. 619-626, 2014.

PEREIRA, O. G.; ROVETTA, R.; RIBEIRO, K. G.; SANTOS, M. E. R.; FONSECA, D. D.; CECON, P. R. Crescimento do capim-tifton 85 sob doses de nitrogênio e alturas de corte. Revista Brasileira de Zootecnia, v. 41, n. 1, p. 30-35, 2012.

RAMOS, B. Z.; PAIS, P. S. A. M.; FREITAS, W. A.; JUNIOR, M. D. S. D. Avaliação dos atributos físicohídricos em um Latossolo Vermelho distroférrico sob diferentes sistemas de manejo-Lavras/Minas Gerais/Brasil. Revista de Ciências Agrárias, v. 36, n. 3, p. 440-446, 2013. 
REICHERT, J. M.; SUZUKI, L. E. A. S.; REINERT, D. J. Compactação do solo em sistemas agropecuários e florestais: Identificação, efeitos, limites críticos e mitigação. In: CERETTA, C.A.; SILVA, L. S.; REICHERT, J. M. Tópicos em Ciência do solo. I. ed. Viçosa: SBCS, v. 5, p. 49-134, 2007.

REYNOLDS, W. D.; BOWMAN, B. T.; DRURY, C. F.; TAN, C. S.; LU, X. Indicators of good soil physical quality: density and storage parameters. Geoderma, v. 110, p. 131-146, 2002.

REYNOLDS, W. D.; DRURY, C. F.; TAN, C. S.; FOX, C. A.; YANG, X. M. Use of indicators and pore volume-function characteristics to quantify soil physical quality. Geoderma, v. 152, p. 252-263, 2009.

REYNOLDS, W. D.; DRURY, C. F.; YANG, X. M.; TAN, C. S. Optimal soil physical quality inferred through structural regression and parameter interactions. Geoderma, v. 146, n. 3, p. 466-474, 2008.

SANTOS, D. S.; ARRUDA, E. M.; MORAES, E. R.; FRANCO, F. O.; ARAÚJO, J. R.; RESENDE, T. M.; BORGES, E. N.; RIBEIRO, B. T. Atributos físicos e Matéria orgânica de áreas de Latossolo utilizadas para atividade pecuária no bioma Cerrado. Bioscience Journal, Uberlândia, v. 28, n. 4, p. 500-508, July/Aug. 2012.
SHI, X. H.; YANG, X. M.; DRURY, C. F.; REYNOLDS, W. D.; MCLAUGHLIN, N. B.; ZHANG, X. P. Impact of ridge tillage on soil organic carbon and selected physical properties of a clay loam in southwestern Ontario. Soil and Tillage Research, v. 120, p. 01-07, 2012.

SILVA, B. M.; OLIVEIRA, G. C.; SERAFIM, M. E.; SILVA, É. A.; OLIVEIRA, L. Índice S no diagnóstico da qualidade estrutural de Latossolo muito argiloso sob manejo intensivo. Bioscience Journal, v. 28, n. 3, 2012.

SOIL SURVEY STAFF. Soil taxonomy: A basic system of soil classification for making and interpreting soil surveys. 2nd edition. Natural Resources Conservation Service. U.S. Department of Agriculture Handbook 436, 1999.

VAN GENUCHTEN, M. T. A Closed-form Equation for Predicting the Hydraulic Conductivity of Unsaturated Soils. Soil Science Society of American Journal, v. 44, n. 5, p. 891-898, 1980.

WALKLEY, A.; BLACK, I. A. An examination of the Degtjareff method for determining soil organic matter and a proposed modification of the chromic acid titration method. Soil Science, Baltimore, v. 37, n. 1, p. 29-38, jan./jun. 1934. 